\title{
TEKNOLOGI TEPAT GUNA PENERAPAN HYDROCOOLING DAN PENYIMPANAN DINGIN UNTUK MEMPERPANJANG UMUR SIMPAN BUAH DAN SAYUR YANG TERKENA ERUPSI GUNUNG SINABUNG
}

\author{
Maya Sari $^{1)}$ Roida Ervina Sinaga ${ }^{2)} J$ liana Br Simbolon ${ }^{3)}$ Robert Sinaga ${ }^{4)}$ \\ ${ }^{1) 2}$ 3)4 4 Universitas Quality \\ Email: mayasari.ugm@gmail.com
}

\begin{abstract}
ABSTRAK
Dampak erupsi Gunung Sinabung sangat mempengaruhi kualitas produksi buah dan sayuran dalam konteks ini adalah buah dan sayur. Buah dan sayur, wortel, strawberry dan pakcoy merupakan jenis buah dan sayuran yang banyak dikonsumsi oleh masyarakat khususnya masyarakat yang ada di sekitaran Gunung Sinabung maupun wilayah kota Medan umumnya. Buah dan sayuran tersebut merupakan salah satu jenis klimaterik maka umur simpannya harus dijaga. Selama pengangkutan dari kebun ke pasar banyak terjadi kerusakan baik kerusakan mekanis maupun fisis. Kerusakan kerusakan ini tentu saja akan merugikan petani, pedagang, dan pelaku pasar lainnya. Oleh karena itu hydrocooling diterapkan sebagai penanganan pascapanen. Hydrocooling segera dilakukan tepat setelah panen, proses ini mampu mengeluarkan panas yang terdapat dalam buah dan sayuran sehingga proses respirasi dan transpirasi dapat berlangsung lama. Kurangnya pemahaman petani terkait penanganan pascapanen menjadi masalah utama. Oleh karena itu, para petani di daerah Berastagi akan diberikan edukasi dan pelatihan terkait penanganan pascapanen ini (hydrocooling) sehingga mereka memahami dan mampu menerapkannya secara mandiri yang nantinya dapat menjaga hasil kebun mereka tetap segar. Adapun output dari kegiatan ini yaitu alat hydrocooling sederhana yang didesain sedemikian rupa sebagai alat peraga saat pelatihan ini dilaksanakan. Alat hydrocooling ini juga bisa menjadi referensi ilmu pelatihan bagi siswa sekolah khususnya sekolah pertanian, dan juga bisa menjadi referensi bagi para peneliti dan mengembangkannya.
\end{abstract}

\section{Kata kunci : buah, sayuran, pascapanen, hydrocooling, penyimpanan dingin}

\begin{abstract}
The effect of Mt. Sinabung eruption has profoundly affected the quality of fruit and vegetable production, in this context is fruit and vegetables. Fruit and vegetable, carrot, strawberry and pakcoy is kind of fruit and vegetable that is consumed by the community especially the communities surrounding both the mountain ranges and the general medan area. The fruit and vegetable are kinds of climateric and the lifespan must be kept. During the transportation of field to market, there wa both mechanical and physical damage.The damage will obviously harm farmers, merchants, and other marketers. So that hydrocooling is applied as a post harvest treatment. Hydrocooling is done right after the harvest, This prosess extracts heat from fruit and vegetables so that respiration and transpiration can continue for a long time. The lack of farmer understanding for post harvest handling is a major problem. Therefore, farmers in aberastagi will be given education and training about post harvest handling (hydrocooling) so they could understand and self applying that will keep their produce fresh. As for the output of this activity is a simple hydrocooling device designed as a visual aid in training. This hydrocooling equipment can also be a reference to training science for schoolchildren in particular agriculture schools and could be a referenceto researchers and developing them.
\end{abstract}

Keyword : Fruit, vegetable, post harvest, hydrocooling, cold storage 


\section{PENDAHULUAN}

Gunung Sinabung merupakan salah satu gunung di Dataran Tinggi Karo, Kabupaten Karo, Sumatera Utara, Indonesia. Koordinat puncak Gunung Sinabung adalah $3^{\circ} 10^{\prime} 12^{\prime \prime}$ LU dan 98 $23^{\prime} 31^{\prime \prime B T}$ dengan puncak tertinggi gunung ini adalah 2.460 meter dpl yang mencapai puncak tertinggi di Sumatera Utara. Gunung ini belum pernah meletus sejak tahun 1600, tetapi mendadak aktif kembali dengan meletus pada tahun 2010 (Anonimous, 2010) ${ }^{[1]}$.

Letusan Gunung Sinabung merusak tanaman pertanian dan perkebunan. Dari seluas 3.863 ha tanaman di enam kawasan, seluas 3.589 ha telah rusak akibat letusan. Hal ini kemudian berdampak pada kelangkaan bahan makanan. Pasokan sayur dan buah menurun hingga 40 persen karena banyak petani tak berani memanen, karena takut bahaya letusan (Retnaningsih, 2013) ${ }^{[2]}$. Menurut Kepala Dinas Pertanian dan Perkebunan Kabupaten Karo, debu vulkanik yang dikeluarkan Gunung Sinabung saat erupsi tidak berpengaruh terhadap tanaman para petani. Berdasarkan erupsi tahun 2010 silam, debu tersebut lebih menyuburkan tanah, namun memerlukan proses waktu yang lama. Tiga tahun silam, erupsi gunung tersebut sangat mengganggu proses pembuahan jenis tanaman Solanase seperti kentang, kubis, buah dan sayur, dan cabai. Karena tanaman tersebut tidak mampu bertahan di lingkungan ekstrim. Tanaman tersebut tidak mampu bertahan di kondisi cuaca ekstrim karena debu vulkanik tersebut mampu membuat daunnya menjadi melepuh. Akan tetapi produksinya tidak berkurang, hanya kualitasnya saja yang menurun (Yonavilbia, 2013) ${ }^{[3]}$.

Setelah panen, buah dan sayuran (buah dan sayur) tentu saja masih melakukan aktivitas metabolisme seperti respirasi dan transpirasi yang dapat menurunkan mutu produk itu sendiri. Laju respirasi merupakan aktivitas metabolik jaringan yang sering digunakan sebagai indikator untuk menentukan laju kemunduran mutu dan kesegaran buah atau sayuran. Semakin cepat laju respirasi pascapanennya, maka akan semakin cepat pula kemunduran mutunya (Apriyanti, 2013) ${ }^{[4]}$. Faktor-faktor biologis lainnya yang dapat dihambat pada buahbuahan dan sayuran yaitu produksi etilen, transpirasi dan faktor morfologis/anatomis. Selain itu, buah dan sayuran harus dihindari dari suhu atau cahaya yang berlebihan

Sebelumnya produk yang dipanen oleh petani langsung dijual ke pengepul lalu pengepul mengirimnya ke Medan tanpa ada kegiatan pascapanen. Hal ini dikarenakan kurangnya pengetahuan petani tentang kegiatan pascapanen. Sebelum sampai ditangan konsumen, buah dan sayuran masih memiliki perjalanan yang panjang mulai dari lapangan/kebun, pengepul buah dan sayuran, pasar besar, pedagang kecil, dan akhirnya sampai ke konsumen. Dengan perjalanan yang panjang, tentu saja akan terjadi kerusakankerusakan yang nantinya bisa mengurangi kualitas baik secara fisik maupun mutu dari buah dan sayuran itu sendiri, misalnya jarak Berastagi ke Medan dan sekitarnya cukup jauh kurang lebih $66,4 \mathrm{~km}$ jadi tentu saja membutuhkan fasilitas yang baik yang mampu menjaga mutu buah dan sayur, selain itu jarak pengangkutan yang cukup jauh akan membutuhkan waktu yang lama untuk sampai di pasar atau konsumen. Menurut Soesanto (2006) ${ }^{[5]}$, produk tanaman yang diangkut dari jarak dekat akan cepat sampai dan akan memperkecil kerusakan yang terjadi sedangkan perjalanan panjang akan mengakibatkan kerusakan mekanis. Kerusakan mekanis ini diakibatkan oleh gesekangesekan, tekanan, selama proses pengangkutan dari daerah penghasil sampai ke tangan konsumen. Selain itu, fasilitas pengangkutan juga harus sesuai, seperti kelengkapan pengatur kelembaban dan suhu di dalam pengangkutan, akan sangat membantu mencegah cepatnya kerusakan pascapanen.

Tanaman hortikultura umumnya termasuk kelompok buah klimakterik, dimana setelah buah dipanen masih melakukan aktivitas metabolisme seperti respirasi, transpirasi dan produksi etilen. Aktivitas tersebut akan mempercepat terjadinya penuaan, pelayuan dan juga pembusukan. Sebagai buah klimakterik, kenaikan pola respirasi produk dapat digunakan sebagai acuan untuk menentukan waktu simpan. Untuk menghambat laju respirasi yang terjadi setelah produk dipanen, beberapa penanganan pascapanen perlu dilakukan. Hal ini bertujuan 
untuk memperpanjang umur simpan produk, sehingga produk masih tetap segar sampai di tangan konsumen.

Mengingat buah dan sayuran bersifat perishable (mudah rusak), banyak produk sebelum sampai di tangan konsumen telah mengalami beberapa penurunan kualitas fisik seperti luka pada buah, beberapa bagian buah sudah lembek/layu, pencoklatan (browning). Oleh karena itu, untuk memperlambat kerusakan ini maka dilakukanlah hydrocooling dan penyimpanan dingin. Pendinginan awal (hydrocooling) pada buah-buahan dan sayuran dapat memperpanjang kesegarannya, hal ini sesuai dengan pernyataan Maya Sari (2015) ${ }^{[6]}$. Buah setelah dipanen segera disimpan di tempat yang dingin atau sejuk, tidak terkena sinar matahari, agar panas yang terbawa dari kebun dapat segera didinginkan dan mengurangi penguapan, sehingga kesegaran buah dapat bertahan lebih lama. Setelah hydrocooling, penyimpanan pada suhu rendah dilakukan guna memperpanjang masa hidup jaringan-jaringan dalam bahan pangan karena aktivitas respirasi menurun dan menghambat aktivitas mikroorganisme. Penyimpanan dingin tidak membunuh mikroba, tetapi hanya menghambat aktivitasnya, oleh karena itu setiap bahan pangan yang akan didinginkan harus dibersihkan lebih dahulu. Jha et al. (2002) ${ }^{[7]}$, menyatakan penyimpanan dingin mengakibatkan terjadinya penurunan kadar air pada buah dan sayur, perubahan kadar antosianin dan nilai chroma pada warnanya (Concellon et al. 2006) ${ }^{[8]}$.

Telah banyak penelitian dilakukan untuk mempertahankan kesegaran buah dan sayuran seperti penyimpanan suhu rendah (Paull, 1999; Fallik et al., 1995) [9], pengemasan dengan atmosfer termodifikasi, dan iradiasi gamma. Disamping itu, penelitian mengenai kombinasi hydrocooling dan penyimpanan dingin masih jarang dilakukan mengingat pentingnya kedua perlakuan ini untuk menjaga kesegaran dan memperpanjang umur simpannya. Ada beberapa metode precooling yaitu room cooling, forced air cooling, vacuum cooling, hydrocooling, hydroair cooling, hydrovacuum cooling, package icing atau contact ice cooling. Salah satu metode yang paling mudah untuk dilakukan oleh para petani maupun industri pertanian adalah hydrocooling karena prosedur yang sederhana dan biaya peralatan juga relatif murah. Oleh karena itu hydrocooling perlu dilakukan sebagai salah satu jenis penanganan pascapanen yang mampu menghilangkan panas lapang yang terbawa saat panen di kebun. Panas ini menjadi pemicu berlangsungnya aktivitas respirasi dan transpirasi secara cepat. Penanganan ini diharapkan mampu memperlambat produk pertanian memasuki fase pembusukan.

\section{METODE PELAKSANAAN}

1. Metode Pemilihan Lokasi

Lokasi dipilih berdasarkan survey daerah produsen buah dan sayur terbanyak di Berastagi dan yang terkena dampak erupsi Gunung Sinabung yaitu desa Rumah Berastagi, Berastagi, Kabupaten Karo.

2. Metode Pelaksanaan

a. Memberikan sosialisasi manfaat dan fungsi penanganan pascapanen kepada kelompok tani buah dan sayur yang menjadi mitra guna menambah wawasan.

b. Memberikan penjelasan tentang serangkaian alat hydrocooling sehingga mereka mampu membuat secara sederhana sekaligus bimbingan cara pemakaiannya.

c. Mengalirkan buah dan sayur ke dalam air dingin yang mengalir lalu menyimpannya pada suhu rendah. Selanjutnya akan diidentifikasi persentase kerusakan produk yang terjadi setelah mendapat perlakuan pascapanen dan dibandingkan dengan produk yang tidak mendapat perlakuan.

d. Mengemas dan menyimpan produk pada suhu rendah.

3. Metode Analisis Data dan Peningkatannya

Setelah dikenai perlakuan maka produk akan dikemas dengan plastik mika lalu disimpan pada suhu rendah. Saat penyimpanan, setiap harinya akan diambil data susut bobot, kadar air, dan perubahan tekstur produk sampai 10 hari penyimpanan. Analisis data dilakukan untuk mendapatkan 
kombinasi perlakuan pascapanen terbaik sehingga dapat diaplikasikan oleh para petani. Selain itu juga mengukur sejauh mana pemahaman mitra kelompok tani akan kegiatan pascapanen tersebut.

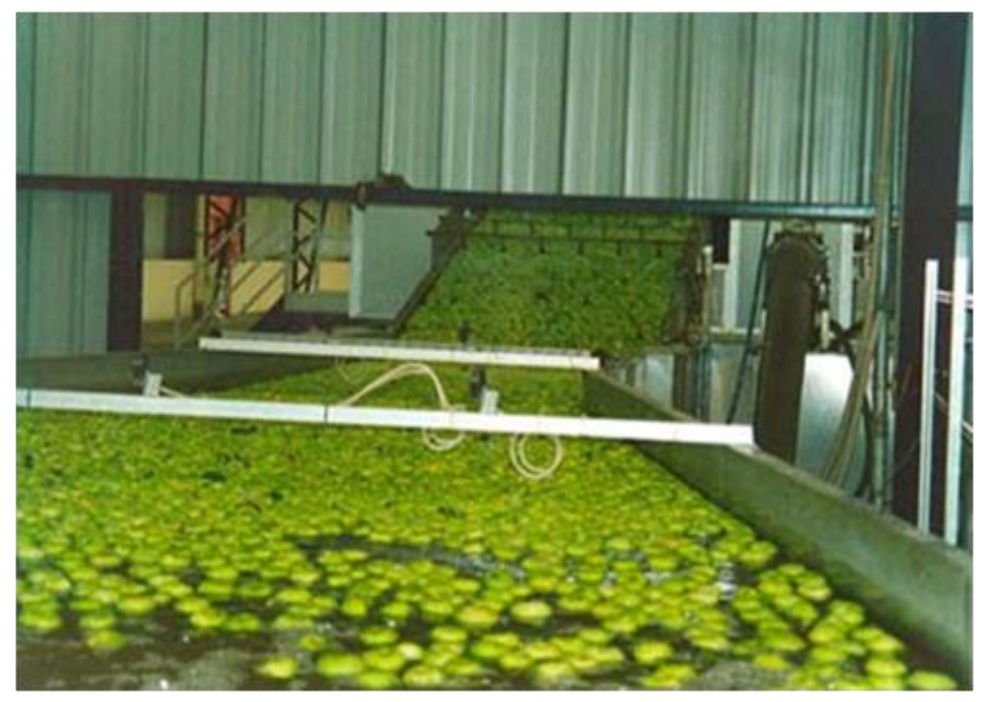

Gambar. Contoh precooling dengan hydrocooling

Sumber: www.fao.org ${ }^{[10]}$

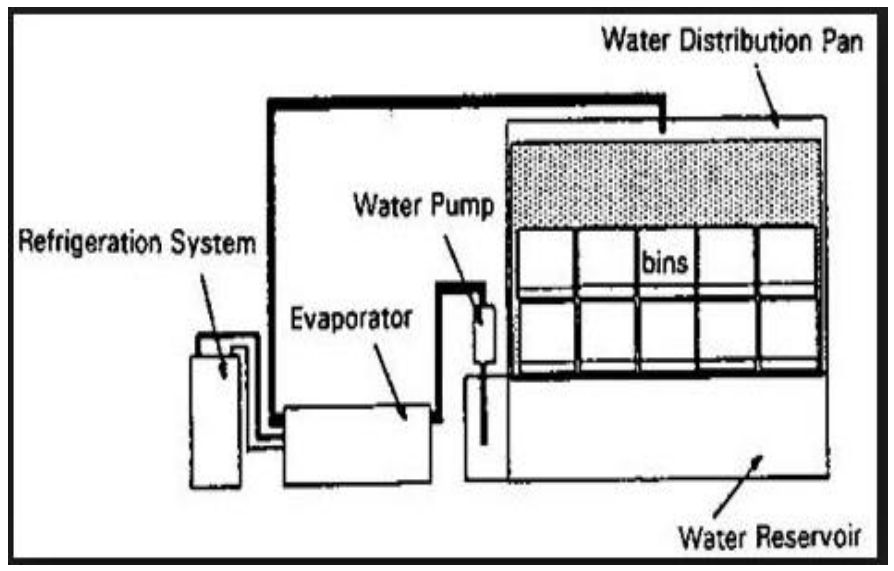

Gambar Hydrocooling tipe batch

Sumber: www.fao.org [11] 


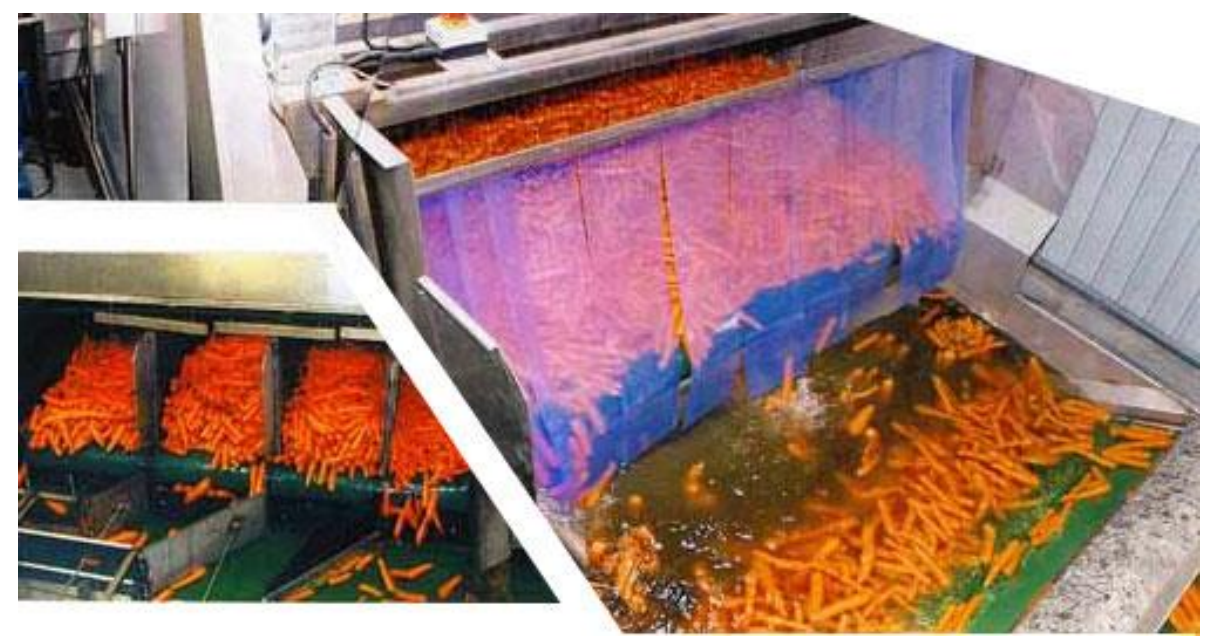

Sumber : armstrongchile ${ }^{[12]}$

\section{HASIL DAN PEMBAHASAN}

\section{Hasil}

Hasil yang didapat dari kegiatan pengabdian masyarakat ini diantaranya adalah :

1. Masyarakat petani diberikan penyuluhan mengenai penerapan hydrocooling dan penyimpanan dingin untuk memperpanjang umur simpan buah dan sayur.

2. Dari hasil penyuluhan, masyarakat petani memahami mengenai isi materi, dan di akhir sesi diberikan waktu tanya jawab. Didapatkan beberapa pertanyaan dari masyarakat petani, diantaranya :
a. Bagaimana cara mengoperasikan alat hydrocooling tersebut?
b. Bagaimana cara memperpanjang umur simpan buah dan sayur?
c. Berapa lama buah dan sayur tersebut bisa dalam kondisi segar?

\section{Pembahasan}

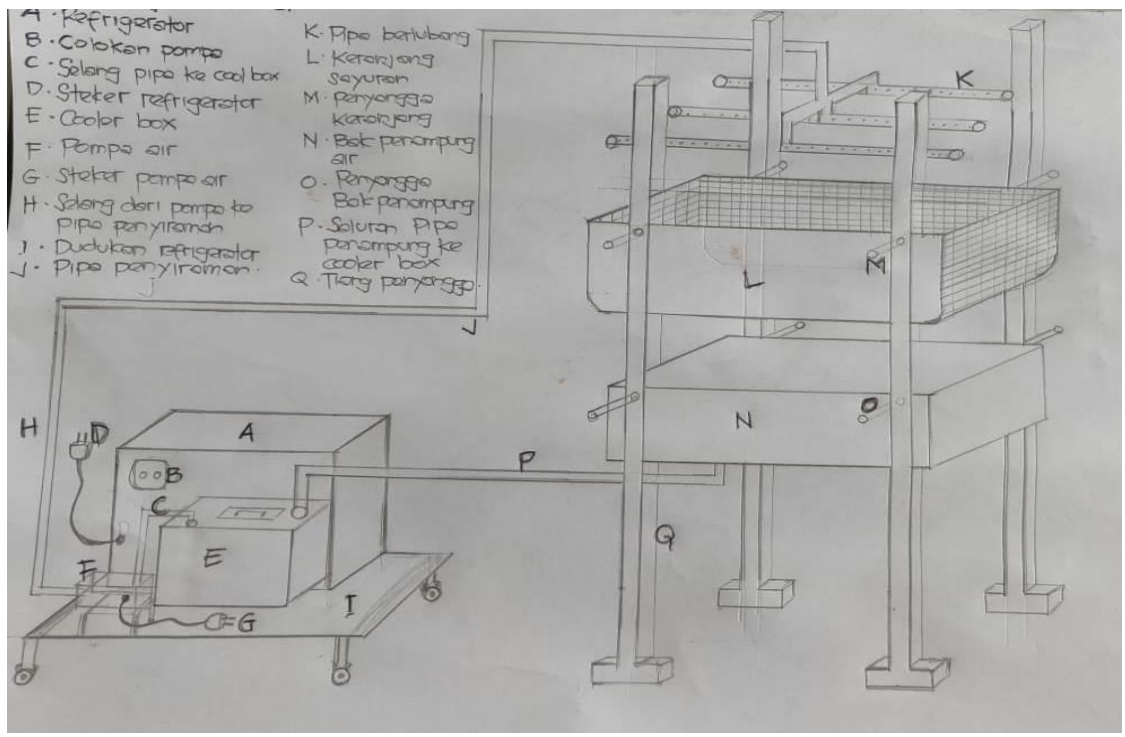



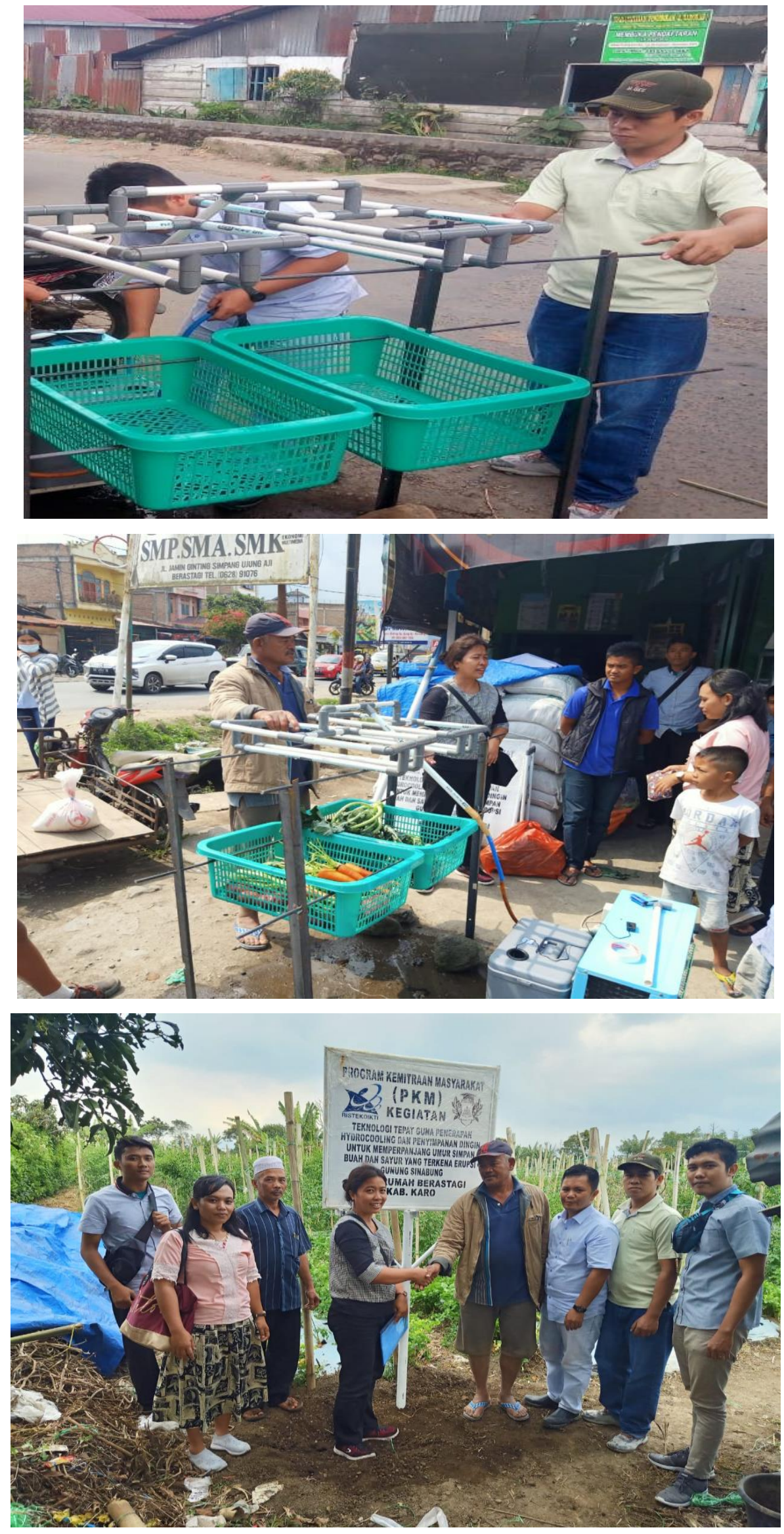


\section{KESIMPULAN DAN SARAN}

\section{Kesimpulan}

1. Kegiatan pengabdian kepada masyarakat stimulan mengenai penyuluhan tentang tentang Teknologi Tepat Guna Penerapan Hydrocooling Dan Penyimpanan Dingin Untuk Memperpanjang Umur Simpan Buah dan Sayur Yang Terkena Erupsi Gunung Sinabung di desa Rumah Berastagi, Kabupaten Karo telah terlaksana dengan baik.

2. Kegiatan pengabdian masyarakat stimulan mengenai penyuluhan tentang tentang Teknologi Tepat Guna Penerapan Hydrocooling Dan Penyimpanan Dingin Untuk Memperpanjang Umur Simpan Buah dan Sayur Yang Terkena Erupsi Gunung Sinabung di desa Rumah Berastagi, Kabupaten Karo mendapatkan respon yang antusias dari masyarakat petani .

3. Didapatkan 3 pertanyaan dari peserta penyuluhan (masyarakat petani) terkait materi penyuluhan dan masyarakat petani tersebut mengharapkan ada kegiatan penyuluhan kembali terkait komoditi Saran selain buah dan sayur.

Kegiatan pengabdian seperti ini dapat dilakukan secara rutin baik di lokasi yang sama maupun di lokasi yang berbeda dengan sasaran masyarakat petani yang benar-benar butuh penyuluhan tentang bagaimana mengembangkan pengetahuan mengenai pertanian.

\section{DAFTAR PUSTAKA}

1. Anonimos. 2010. Gunung Sinabung. Tersedia pada: https://id.wikipedia.org/wiki/Gunung Sina bung. Diakses pada hari Senin, 27 Agustus 2018. Pukul 12.06 WIB

2. Retnaningsih, dkk. 2013. Analisis Perilaku Pembelian Buah di Pedesaan dan Perkotaan. Jurnal Ilmu Keluarga dan Konsumen. Vol. 6 No. 2. Departemen Ilmu
Keluarga dan Konsumen, Fakultas Ekologi Manusia, Institut Pertanian Bogor.

3. Yonavilbia, E. 2013. "Dinas Pertanian dan Perkebunan Pemkab Karo Jamin Debu Vulkanik Erupsi Sinabung Tak Pengaruhi Tanaman". Medan Bagus. 20 September 2013.

4. Apriyanti M., 2013. Analisis Matematis Laju Respirasi dan Perubahan Sifat Fisik Buah Tomat (Lycopersicon esculentum Mill) dengan Pengaruh Vibrasi dan Penyimpanan Suhu Dingin . Tesis Pascasarjana UGM. Yogyakarta.

5. Soesanto, Loekas. 2006. Penyakit Pascapanen Sebuah Pengantar. Penerbit Kanisius.

6. Sari, Maya. 2015. "Analisis Matematis Pengaruh Precooling dan Penyimpanan Dingin Terhadap Kualitas Fisik Terong (Solanum melongena L.) Tesis Pascasarjana UGM. Yogyakarta.

7. Jha, S.N; Matsuoka T; Miyauchi K. 2002. Surface gloss and weight of eggplant during storage. Biosystems Engineering. 81. 407-412.

8. Concellon, A., Anon, M. C., and Chaves, A. R. 2006. Effect of low temperature storage on physcal and physiological characteristics of eggplant fruit (Solanum melongena L.) Food Chemistry. 389-396.

10. Fallik E; Naomi T G; Shoshana G; Davidson H (1995). Prolonged low temperature storage of eggplants in polyethylene bags. Postharvest Biology and Technology, 5, 83-89.

11. Paull, E. R. (1999). Effect of temperature and relative humidity on fresh commodity quality. Postharvest Biology and Technology, 15, 263-277.

12. FAO Corporate Document Repository. 2015a. Chapter 2 Preparation for The Fresh Market. www.fao.org/docrep/008/y4893e/y4893e 05.htm. [1 Juni 2015]. 
13. FAO Corporate Document Repository. 2015b. Section 6. Temperature and Relative Humidity Control. www.fao.org/wairdocs/x 5403e08.htm. [1 Juni 2015].

14. Armstrong Chile. Hidrocooler Para Zanahorias Papas Y Hortalizas Haith.

http://www.armstrongchile.cl/products/vi ew/199. Diakses pada hari Kamis, 30 Agustus 2018
15. Pujimulyani, Dwiyanti. 2011. Teknologi Pengolahan Sayur-sayuran dan Buahbuahan. Graha Ilmu. Yogyakarta.

16. Santoso, Umar. 1991. Respirasi dan Teknik-teknik Pengukurannya. Fakultas Teknologi Pertanian. Universitas Gadjah mada.

17. Tranggono dan Suhardi, 1990. Biokimia dan Teknologi Pascapanen. Pusat Antar Universitas (PAU) Pangan dan Gizi. Gadjah Mada University press, Yogyakarta. 